\title{
Analysis of Influence of Product Quality and Price on Buyer's Decision
}

\author{
Mukson \\ Muhadi Setiabudi University, Indonesia \\ E-mail:mukson@umus.ac.id \\ Mohamad Badrun Zaman \\ Muhadi Setiabudi University, Indonesia \\ E-mail: badrunmohamad93@gmail.com \\ Syariefull Ikhwan \\ Muhadi Setiabudi University, Indonesia \\ E-mail:Syarief20tmi@gmail.com
}

\begin{abstract}
The product's quality and price are two considerations that consumers weigh before making a purchase. With the Gebug milkfish micro, small, and medium enterprises (MSME), as many as 17 businesses in Losari District, Brebes Regency, this study aims to evaluate the impact of product quality and price on customer satisfaction. The participants in this study were 212 Losari District buyers of MSME milkfish products. With a total sample size of 34 consumers, this analysis used the random sampling technique. Quantitative analysis using a survey approach was used in this study. The price variable received a T-count value of 4,196 with a significance value of 0.001 less than 0.05 (0.001 0.05) based on the results of the t-test statistic, and the regression coefficient has a positive value of 0.715 , so it can be inferred that the commodity price has a positive impact on buying decisions. The regression coefficient has a negative value of -0.148 , and the T-test statistical results of the product quality variable obtained a $t$ value of -0.748 with a significant value of 0.459 greater than $0.05(0.4590 .05)$ that the quality of a commodity has a positive impact on buying decisions. In this research, product quality and price influence buyer decisions for Gebug milkfish in Brebes Regency's Losari District. Since the regression coefficient is negative (-0.148), it can be inferred that product quality positively impacts buying decisions. In this research, product quality and price influence buyer decisions for Gebug milkfish in Brebes Regency's Losari District. Since the regression coefficient is negative (-0.148), it can be inferred that product quality positively impacts buying decisions. In this research, product quality and price influence buyer decisions for Gebug milkfish in Brebes Regency's Losari District.
\end{abstract}

\section{Keywords: Quality, Product Price, and Customer Satisfaction}

Received: 24 March 2021;

Accepted: 4 June 2021 ;

Publish: June 2021

\section{How to Cite:}

Mukson, Zaman, M.B., \& Ikhwan, S. (2021). Analysis of Influence of Product Quality and Price on Buyer's Decision. Journal of Business and Behavioural Entrepreneurship, 5(1), 149-160 https://doi.org/10.21009/JOBBE.005.1.10 


\section{INTRODUCTION}

The growth of micro, small, and medium enterprises (MSMEs) in Indonesia is coinciding as its economy grows. According to UMKM data from the Ministry of Cooperatives' website http://www.depkop.go.id/data-umkm, MSMEs have a rise from year to year that is still negligible. The increase only ranges between $2 \%$ and $4 \%$. However, when measured in terms of the increase in MSME actors' jobs, it is substantial, ranging from $1 \%$ to $8 \%$. It can be concluded that every MSME can generate jobs, which is hugely beneficial to Indonesia's economy. In Indonesia, the leading market players are small and medium-sized enterprises (SMEs). MSME actors have stood firm and continued to develop despite the numerous shocks of Indonesia's economic crisis. Environmental principles apply to MSMEs in compliance with Law No. 20 of 2008. Environmental awareness is a philosophy that empowers micro, small, and medium-sized business owners.

Money, market share, price, quality, and quantity provided to consumers or customers all play a role in MSMEs' growth. The price and quality of an object or commodity are the most critical factors affecting MSME players. Price is one of the most important factors that consumers consider when deciding whether to purchase a commodity in an item or a service. According to Kotler and Keller (2009: 23), price is a component of the marketing mix that defines a product's profitability and value. Prices in line with the quality and quantity of a commodity would entice customers to purchase it; additionally, the price of a product being sold is below the current market value. Price is one of the marketing factors that company management must pay attention to, according to Nasution (2006: 117), because price directly impacts revenue and company income. Prices have a particular appeal for buyers, so producers must be careful when setting prices. Company actors, including businesses and home enterprises, would have difficulty selling their goods if there is a price mistake. Kotler (2009: 87) goes on to say that relevant to product quality is something that can be sold to the market in order to attract potential customers' attention. (Geovani, S.M et al., 2021)Which are then bought by customers and used or consumed to fulfill their wants or needs. A product is a product or service that is ready to be sold and used by customers in order for them to experience its advantages and meet their needs. A product's capacity to perform its duties, including durability, reliability or schedule, weight, ease of product packaging and maintenance, and other characteristics, is specified by private (2002: 126). A product can be put on the market to gain consumer interest, buy, use, or consumption while still meeting the consumer's needs. The commodity is a subjective perception of the producer that can be produced to satisfy customers' needs and activities to achieve corporate objectives based on its resources and buying power in the market.

Furthermore, goods can be in the form of customer expectations clarified by manufacturers through their production results. Consumers regard products as valuable and use them as a basis for purchasing decisions. Tipton (2008: 152) describes how price is used to present a product to consumers in terms of its features, such as quality. This issue has the most impact on an environment where consumers struggle to calculate aspects of creation or efficacy critically. The common misconception is that a high price represents high quality.

Essentially, customers purchase a commodity in order to fulfill their needs and wishes. Consumers' wishes will be met if the product's quality and quantity and its flavor, packaging, and size align with the price value. Product quality is the deciding factor in customer satisfaction after they have purchased and consumed a product. 
Milkfish gebug, researchers see an up-and-coming business in Losari District, Brebes Regency, Central Java, where this business is carried out in almost every village, and buyers are also quite a lot both from their region and from outside. This is what attracts researchers to these issues in Indonesia's different regions and even provinces. (Chenavaz et al., 2020)

\section{LITERATURE REVIEW}

\section{Product quality}

According to Alfred (2013: 99), quality is defined as providing information about a product's description and how to use it before consumers make a purchase. Quality aims to satisfy customers, so product quality can be characterized as a product's features or characteristics that satisfy customers by meeting their needs and desires. Lutfia (2012: 55) describes quality as a product's ability to carry out its intended functions, including product resistance energy for eating, sharing data about a product's effectiveness, and sharing data about the production process. Product quality is described by Kotler and Armstrong (2012: 189) as a characteristic of a product's ability to meet the needs that have been set by customers and have a latent character. Product quality is intended to share all information gathered during the development of a product that has been tested to meet customer needs.(Kotler, 2007)

\section{Product Prices}

Price is described by Ari Setyaningrum (2015: 128) as a portion of the money required to obtain a product or service. Historically, the primary factor affecting a buyer's decision has been price. Pricing is an important and environmentally friendly aspect of marketing management. On the one hand, price-fixing is a critical strategic factor in the marketing mix because it emphasizes that price is more important than quality and contributes significantly to product positioning. Describes price as a portion of the money required by customers to receive a partial mixture of a product and service to meet their everyday needs.

\section{Buying decision}

According to Etta (2013: 120), a decision is to choose one action from a collection of alternatives that must be tried. An integration process that integrates experience to compare two or more alternative attitudes and sort out one of them is at the core of making buying decisions. Tjiptono's (2008: 21) purchasing decision is a mechanism in which the buyer identifies the problem, searches for data on specific goods or brands, and considers a portion of each of these alternatives to include them in solving the problem which contributes to the purchase decision. According to Kotler (2007: 223), a purchasing decision is a stage that customers go through before making a commodity purchase decision.

\section{RESEARCH METHOD}

The type of research applied in this research is quantitative research, where research information is in the form of numbers and is analyzed using statistics. The pro- 
cedure used in this research is a survey procedure. With 17 micro, small and medium enterprises (UMKM) actors of Gebug milkfish in Losari District, Brebes Regency. Taken the population by random sampling as much as 212 consumers and then taking a sample of 34 consumers, the data is processed using SPSS Version 25.00.

\section{Frame of mind}

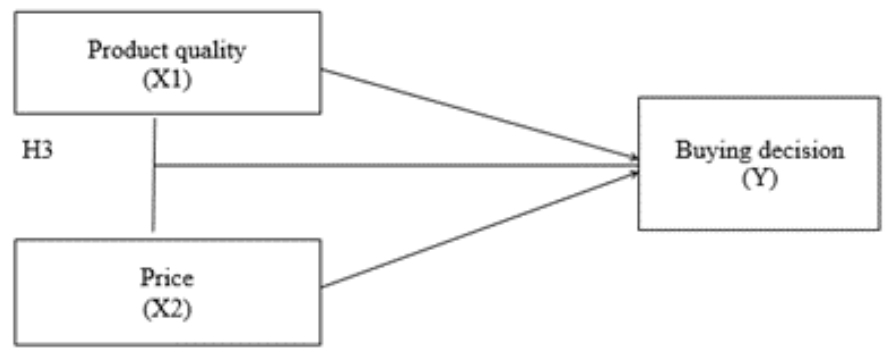

Figure 1. Framework

Information

$\mathrm{H} 1$ is the effect of product quality on consumer purchasing decisions.

$\mathrm{H} 2$ is the effect of price on purchasing decisions.

$\mathrm{H} 3$ is the effect of product quality and price on purchasing decisions.

\section{RESULTS AND DISCUSSIONS}

\section{Classic assumption test \\ Normality test}

The information normality test aims to test whether the dependent and independent variables are in a fair distribution, close to reasonable, or not. The normality test of information in this research is tried by looking at the histogram graph of information, which is declared reasonable. If the shape of the curve has a slope that tends to be balanced, either from the right or the left side and the curve almost matches the shape of an almost perfect bell. The data is declared normal when the image is distributed with the data points in the diagonal line's direction in the standard P-Plot image.

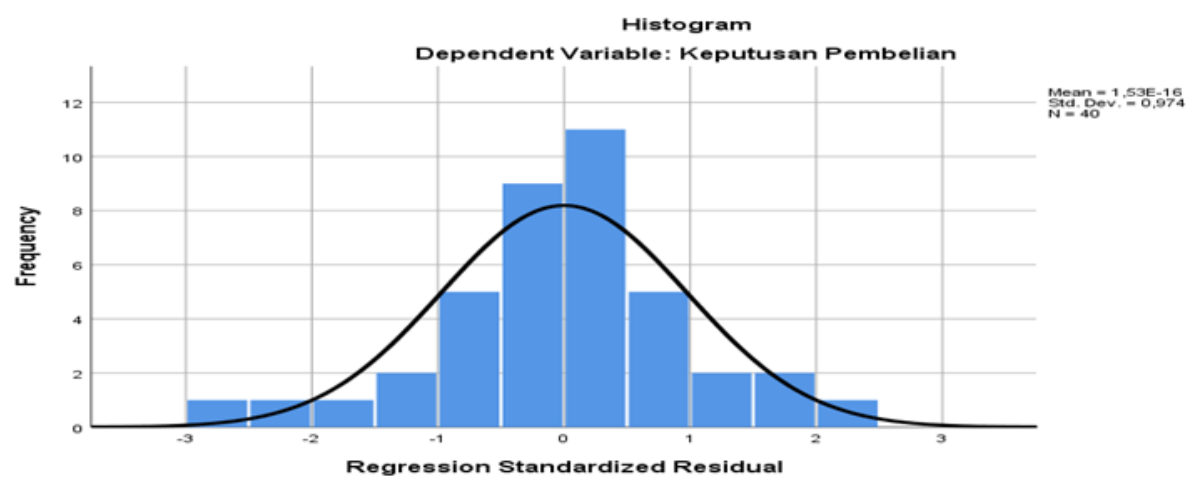

Figure 1. E-Money User 
Based on Figure 2, the graph above shows that the distribution of data on the histogram line display can be concluded that the histogram graph provides a normal distribution.

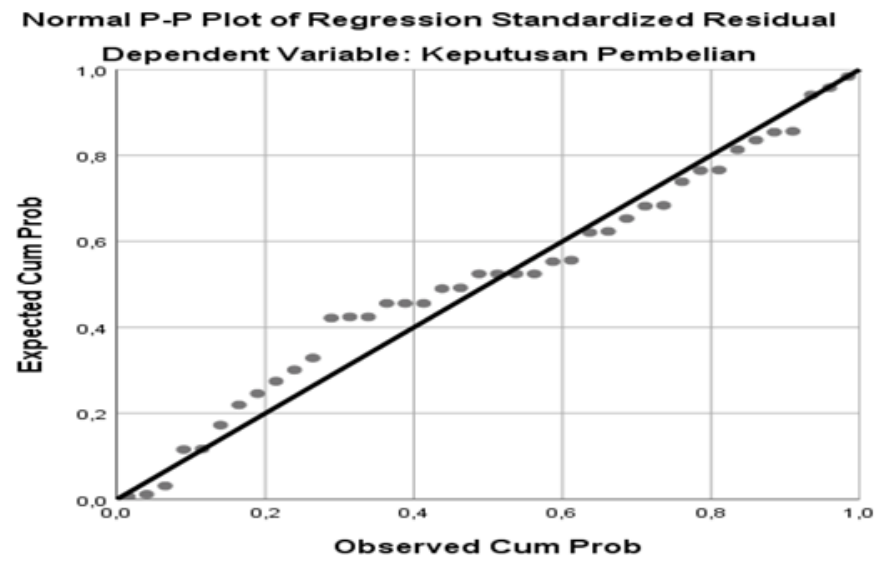

Figure 3.Normal P-Plot

Based on Figure 3, it can be seen that the distribution of data points is distributed along the diagonal, and the distribution of data points follows the diagonal line, so it can be concluded that the regression meets normality.

\section{Multicollinearity test}

The multicollinearity test helps determine whether the proposed regression model finds a strong correlation between the independent variables. If the variance inflation factor (VIF) value $<10$ and the tolerance value $>0.10$, it can be concluded that there is no multicollinearity between the independent variables in the regression model.

Table 1. Output Multicollinearity Cofficientsa

\begin{tabular}{|c|r|r|}
\hline \multirow{2}{*}{ Model } & \multicolumn{2}{|c|}{ Collinearity Statistics } \\
\cline { 2 - 3 } & Tolerance & \multicolumn{1}{c|}{ VIF } \\
\hline (Constant) & & \\
Price & .907 & 1,103 \\
Product quality & .907 & 1,103 \\
\hline
\end{tabular}

As shown in Table 1, the VIF value of the price variable is 1.103, and the tolerance value is 0.907 . Although the quality variable has a VIF value of 1.103 and a tolerance value of 0.907 , in all these variables, the tolerance value is $0.907>0.10$, and the VIF value is $1.103<10$.

\section{Heteroscedasticity test}

Examine differences in the residual variance from one observation period to another, or draw the relationship between the predicted scores and the students' elimination residual scores. From the scatter plot image mode, we can see how to predict 
the presence or absence of heteroscedasticity in the model. In the multiple regression model, there is no heteroscedasticity. If the dots are spread above, below, or around or around the number 0 , the regression model will not experience heteroscedasticity.

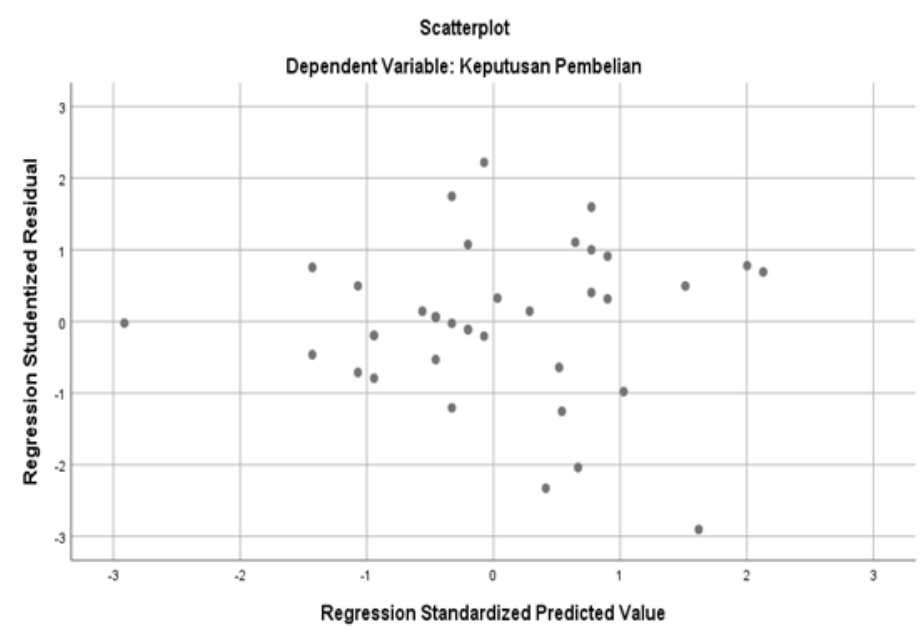

Figure 4.Scatterplot

Figure 4 shows that the scatter plot points are scattered randomly and are spread above or below the number 0 . Therefore, it can be concluded that there is no heteroscedasticity in the regression model, so the questionnaire model is suitable for improving decision-making, purchasing milkfish worms in Losari Brebes Regency, based on independent variables (price and product quality).

\section{Linearity Test}

Table 2. Results of the Linearity Anova test of Product Quality

\begin{tabular}{|c|c|c|c|c|c|c|c|}
\hline & & & $\begin{array}{l}\text { Sum of } \\
\text { Squares } \\
\end{array}$ & df & Mean Square & $\mathrm{F}$ & Sig. \\
\hline \multirow{5}{*}{$\begin{array}{l}\text { Purchase De- } \\
\text { cision* } \\
\text { Product } \\
\text { Quality }\end{array}$} & \multirow{3}{*}{$\begin{array}{l}\text { Between } \\
\text { Groups }\end{array}$} & (Combined) & 24,074 & 7 & 3,439 &, 799 &, 594 \\
\hline & & Linearity &, 920 & 1 &, 920 &, 214 &, 647 \\
\hline & & $\begin{array}{l}\text { Deviation from } \\
\text { Linearity }\end{array}$ & 23,155 & 6 & 3,859 &, 897 &, 509 \\
\hline & \multicolumn{2}{|c|}{ Within Groups } & 137,701 & 32 & 4,303 & & \\
\hline & \multicolumn{2}{|l|}{ Total } & 161,775 & 39 & & & \\
\hline
\end{tabular}

Linearity test is used to determine the form of the relationship between the independent variables and the dependent variable. 


\section{Table 3: Price Linear Anova test results}

\begin{tabular}{|c|c|c|c|c|c|c|c|}
\hline & & & $\begin{array}{l}\text { Sum of } \\
\text { Squares }\end{array}$ & $\mathrm{df}$ & Mean Square & $\mathrm{F}$ & Sig. \\
\hline \multirow{5}{*}{$\begin{array}{l}\text { Purchase } \\
\text { Decision } \\
* \text { Price }\end{array}$} & \multirow{3}{*}{$\begin{array}{l}\text { Between } \\
\text { Groups }\end{array}$} & (Combined) & 72,671 & 7 & 10,382 & 3,728 &, 005 \\
\hline & & Linearity & 51,143 & 1 & 51,143 & 18,367 &, 000 \\
\hline & & $\begin{array}{l}\text { Deviation from Line- } \\
\text { arity }\end{array}$ & 21,528 & 6 & 3,588 & 1,289 &, 290 \\
\hline & \multicolumn{2}{|c|}{ Within Groups } & 89,104 & 32 & 2,784 & & \\
\hline & \multicolumn{2}{|l|}{ Total } & 161,775 & 39 & & & \\
\hline
\end{tabular}

Based on the data above, it is known that the fundamental value of decision making is known as the Sig. Deviation from linearity product quality $0.509>0.05$, and the value of Sig. Deviation from linearity at $0.290>0.05$, it can be concluded that there is a linear relationship between the independent variables and the dependent variable.

\section{Autocorrelation test}

The autocorrelation test aims to test whether there is a correlation between the confounding error period $t$ and the confounding error period $t-1$ in the (previous) linear regression model. If there is a correlation, it is called an autocorrelation problem. The following is the calculation data:

Table 4: Durbin Watson test results

\begin{tabular}{|l|c|r|r|r|r|}
\hline Model & R & R Square & $\begin{array}{c}\text { Adjusted R } \\
\text { Square }\end{array}$ & $\begin{array}{c}\text { Std. The error of } \\
\text { the Estimate }\end{array}$ & Durbin-Watson \\
\hline 1 &, $571 \mathrm{a}$ &, 326 &, 290 & 1,71626 & 1,826 \\
\hline
\end{tabular}

Table 5. Durbin Watson Value Calculation

\begin{tabular}{|c|c|c|c|c|}
\hline $\mathrm{d}$ & $\mathrm{Dl}$ & $\mathrm{du}$ & $4-\mathrm{dl}$ & $4-\mathrm{du}$ \\
\hline 1,826 & 1.3908 & 1,6000 & 2.6092 & 2,400 \\
\hline
\end{tabular}

Based on the table above, the equation was tested with the Durbin Watson autocorrelation test, namely $\mathrm{du}<\mathrm{d}<4$-du, so the results were $1,600<1,826<2,400$, so it can be concluded that no autocorrelation occurs in variables X1 and X2 with variable Y. 


\section{Hypothesis testing}

\section{T-test (partial)}

The t-test is used to partially test the effect of each independent variable of product quality and price (X1 and X2) on the dependent variable on purchasing decisions (Y). This test uses the criteria if $\mathrm{t}$-count $>\mathrm{t}$-table, then $\mathrm{Ha}$ is accepted and $\mathrm{H} 0$ is reject$\mathrm{ed}$, or the independent variable has a significant effect on the dependent variable. If $<\mathrm{t}-$ table, $\mathrm{Ha}$ is rejected and $\mathrm{H} 0$ is accepted, or the independent variable does not significantly affect the dependent variable. $\mathrm{T}$ table $=$ (confidence level divided by 2 number of responses, minus 1). Alternatively, it can also use the following formula:

\section{Hypothesis testing}

\section{T-test (partial)}

The t-test is used to partially test how each independent variable (X1 and X2) product quality and price affect the dependent variable $(\mathrm{Y})$ purchasing decisions. If $\mathrm{t}-$ count $>\mathrm{t}$-table, this test uses the standard, then accepts Ha and rejects $\mathrm{H} 0$ or the independent variable significantly affects the dependent variable. If $<\mathrm{t}$ table, then $\mathrm{Ha}$ is rejected, H0 is accepted, or the independent variable has no significant effect on the dependent variable. $\mathrm{T}$ table $=$ (number of responses with confidence level divided by two minus 1). Alternatively, it can also use the following formula:

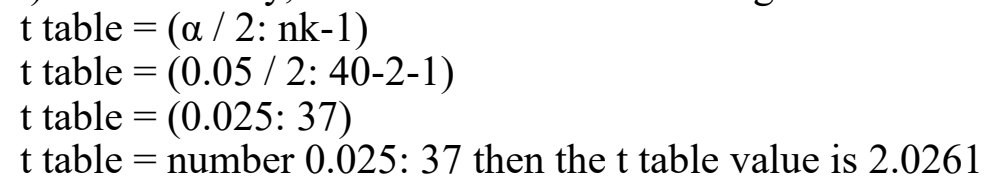

Table 6. Test Results

\begin{tabular}{|c|c|c|c|c|c|c|}
\hline & \multirow{2}{*}{ Model } & \multicolumn{2}{|c|}{ Unstandardized Coefficients } & \multirow{2}{*}{$\begin{array}{c}\begin{array}{r}\text { Standardized } \\
\text { Coefficients }\end{array} \\
\text { Beta }\end{array}$} & \multirow[t]{2}{*}{$\mathrm{t}$} & \multirow{2}{*}{ Sig. } \\
\hline & & B & Std. Error & & & \\
\hline \multirow[t]{3}{*}{1} & (Constant) & \begin{tabular}{|c|}
6,974 \\
\end{tabular} & 3,562 & & 1,958 &, 058 \\
\hline & Product quality & \begin{tabular}{|c|}
,- 148 \\
\end{tabular} &, 198 &,- 106 &,- 748 & $\overline{, 459}$ \\
\hline & Price & .715 & 170 & .595 & 4,196 & 000 \\
\hline
\end{tabular}

From table 6 regarding the test results, the results can be seen, namely:

\section{The Effect of Product Quality on Purchasing Decisions}

Based on the output coefficient on product quality, the $t$ value is $-748<\mathrm{t}$ table 2.0261 and the significance value (Sig.) $0.459>0.05$, it can be concluded that $\mathrm{H} 0$ is accepted $\mathrm{H} 1$ is rejected. It means that the product quality variable does not have a partial effect on the purchasing decision variable of Gebug milkfish buyers in the Losari sub-district, Brebes district. Based on the t-test statistical product quality variable results, the t-count value is -0.748 with a significance value of 0.459 greater than 0.05 $(0.459<0.05)$. Furthermore, the regression coefficient has a negative value of -0.148 . The hypothesis states that there is a positive effect of the influence of product quality on purchasing decisions (Case study on buyers of Gebug milkfish in Losari subdistrict, Brebes Regency) Rejected. 


\section{Effect of Price on Purchasing Decisions}

Based on the output coefficient about the price, the $t$ value is $4.196<\mathrm{t}$ table 2.0261 and the significance value (Sig.) $0.000<0.05$, it can be concluded that $\mathrm{H} 0$ is rejected and $\mathrm{H} 1$ is accepted. It means that the price variable has a partial effect on the purchasing decision variable of Gebug milkfish buyers in the Losari sub-district, Brebes district. Based on the results of the t-test statistic, the price variable obtained an at-value value of 4,196 with a significance value of 0.001 less than $0.05(0.001<0.05)$, and the regression coefficient has a positive value of 0.715 , so the hypothesis that there is influence positive effect of price on purchasing decisions (Case study on buyers of Gebug milkfish in Losari sub-district, Brebes district) Accepted.

\section{F test (simultaneously)}

Simultaneous testing aims to determine whether the independent variables (price and quality) have the same effect on the dependent variable (purchase decision). If the $p$-value $<$ from the specified level of significance, then the test uses this standard, then the independent variables affect the dependent variable. It can be seen the value of $F$. If the F count $>F$ table's value, then the independent variable affects the dependent variable. Table F can be calculated by $\mathrm{df} 1=\mathrm{k}-1$ and $\mathrm{df} 2=\mathrm{nk}$, where $\mathrm{k}$ is the number of dependent and independent variables. Then $\mathrm{df} 1=3-1=2$ and $\mathrm{df} 2=34-3=31$, so that the F table we get is 3.30 .

Table 7. Test Results F

\begin{tabular}{|l|l|r|r|r|r|r|}
\hline Model & Sum of Squares & df & Mean Square & F & Sig. \\
\hline 1 & Regression & 52,789 & 2 & 26,395 & 8,961 &, $001 \mathrm{~b}$ \\
\cline { 2 - 7 } & Residual & 108,986 & 37 & 2,946 & & \\
\cline { 2 - 7 } & Total & 161,775 & 39 & & & \\
\hline
\end{tabular}

From table 7 the Anova F Test Results, the explanation of the calculation results is known as follows:

a. $\quad$ The value of F-count $=8,961$ and F-table $=3.24$, so F-count $>$ F-table, meaning that the price and quality variables influence purchasing decisions for milkfish buyers in the Losari sub-district, Brebes district.

b. The significant value is $0.001<0.05$, which significantly affects Gebug milkfish buyers' purchasing decisions in the Losari sub-district, Brebes district.

\section{Test the coefficient of determination (R2)}

The coefficient of determination (R2) measures the willingness of the model to explain the dependent variable. If R2 is large (close to 1), it can be said that the effect of the independent variable is the same as the dependent variable. The model used is increasingly powerful and can explain the independent variable's effect on the dependent variable. Meanwhile, $\mathrm{R}^{2}$ (close to zero) means that the effect of the independent variables (X1 and $\mathrm{X} 2$ ) on the dependent variable $(\mathrm{Y})$ is getting smaller, which means that the model used is not sufficient to explain this effect. Of the independent variable on that variable. 


\section{Table 8. Model Summary}

\begin{tabular}{|l|c|c|c|c|}
\hline Model & $\mathrm{R}$ & R Square & $\begin{array}{c}\text { Adjusted R } \\
\text { Square }\end{array}$ & $\begin{array}{c}\text { Std. The error of } \\
\text { the Estimate }\end{array}$ \\
\hline 1 &, $571 \mathrm{a}$ &, 326 &, 290 & 1,71626 \\
\hline \multicolumn{2}{|l|}{ a. Predictors: (Constant), Price, Product Quality } \\
\hline
\end{tabular}

The data analysis results in table 6 , the value of $\mathrm{R}=0.571$ or $\mathrm{R}^{2}$ ( $\mathrm{R}$ Square $)=$ 0.326 . It means that the regression model obtained can explain that the variable product quality (X1) and price (X2) can influence purchasing decisions on milkfish buyers in the Losari sub-district, Brebes district $45.9 \%$. In comparison, the rest is influenced by other variables.

\section{Model Test}

\begin{tabular}{|c|c|c|c|c|c|}
\hline \multicolumn{6}{|c|}{ Table 9.Coefficients } \\
\hline \multirow[b]{2}{*}{ Model } & \multicolumn{2}{|c|}{$\begin{array}{c}\text { Unstandardized Coeffi- } \\
\text { cients }\end{array}$} & \multirow{2}{*}{$\begin{array}{c}\begin{array}{r}\text { Standardized } \\
\text { Coefficients }\end{array} \\
\text { Beta }\end{array}$} & \multirow[b]{2}{*}{$\mathrm{t}$} & \multirow[b]{2}{*}{ Sig. } \\
\hline & B & Std. Error & & & \\
\hline \begin{tabular}{|l|l}
1 & (Constant)
\end{tabular} & 6,974 & 3,562 & & 1,958 & 058 \\
\hline Product quality &,- 148 &, 198 &,- 106 &,- 748 &, 459 \\
\hline Price & 715 & 170 & 595 & 4,196 & 000 \\
\hline
\end{tabular}

Based on the results of the data in table 6, the regression equation is obtained as follows:

$$
\mathrm{Y}=\mathbf{a}+\boldsymbol{\beta 1} \mathbf{X} 1+\boldsymbol{\beta 2} \mathbf{X} 2+\mathrm{e}
$$

So from the model above, the SPSS output results can be entered as follows:

$$
\mathrm{Y}=6,974+-0,148 \times 1+0,715 \times 2+e
$$

The constant value is 6,974 , which means that if the product quality variable (X1) and the price variable (X2) is assumed to be zero, then the buying decision of milkfish buyers in Losari District, Brebes Regency, will change. Assuming the other variables are constant or constant, multiply by 7,541. The regression coefficient value of the product quality variable $(\mathrm{X} 1)$ is -0.148 , which means that the product quality variable (X1) has no positive effect on purchasing decisions.

The regression coefficient value of the price variable (X2) is 0.715 , which means the price variable (X2) positively affects purchasing decisions. In other words, every time the price variable (X2) increases by one unit, for milkfish buyers, In other words, the purchase decision is made at Gebug. In the Losari area, assuming other variables are constant or constant, Brebes will increase by 0.715 . 


\section{CONCLUSIONS AND SUGGESTIONS}

Based on the results of research and discussion of the effect of product quality and price on purchasing decisions, as well as exemplifying Gebug milkfish buyers in Losari sub-district, Brebes district, the following conclusions can be drawn:

1. Product quality does not affect the buying decision of milkfish buyers in Losari District, Brebbs Regency. It can be seen from the $t$ value of -0.748 , the significance value of 0.459 is more significant than $0.05(0.459<0.05)$, and the regression coefficient is negative -0.148 , so it can be concluded that the variable product quality obscures Gebug in Losari District, Brebes Regency. The decision to buy fish does not affect.

2. Price affects the buying decision of milkfish buyers in Losari District, Brebes Regency. It can be seen from the $t$ value of 4.196 , the significance value of 0.001 is less than $0.05(0.001<0.05)$, and the regression coefficient has a positive value of 0.715 , so it can be concluded that the price variable has a positive value score. It has a significant effect on Gebug milkfish buyers' buying decision in Losari District, Brebes Regency.

3. Price affects the buying decision of milkfish buyers in Losari District, Brebes Regency. It can be seen from the $t$ value of 4.196 , the significance value of 0.001 is less than $0.05(0.001<0.05)$, and the regression coefficient has a positive value of 0.715 , so it can be concluded that the price variable has a positive value score. It has a significant effect on Gebug milkfish buyers' buying decision in Losari District, Brebes Regency.

4. The effect of product quality and price has a different effect on Gebug milkfish buyers' purchasing decisions in Losari District, Brebes Regency. It can be seen from the $\mathrm{F}$ test (at once), $\mathrm{F}$ count $=8.961, \mathrm{~F}$ table $=3.24$, so that the practical value of $\mathrm{F}$ count $>\mathrm{F}$ table is 0.001 . Therefore, the significant value is less than $0.05(0.000<0.05)$, so it can be concluded that the price variable and product quality variable together have a positive and significant effect on purchasing decisions of Gebug milkfish buyers in Losari District Brebes Regency.

\section{REFERENCES}

Alfred. (2013). Influences of Price And Quality On Consumer Purchase Of Mobile Phone In The Kumasi Metropolis In Ghana A Comparative Study. European Journal of Business and Management, 5 (1), p. 179-199.

Ari Setyaningrum, J.U. (2015). Marketing Principles. Yogyakarta: Andi.

Ariyoto. (2001). Operations Management Principles, translated by Kresnohadi Ariyoto. Salemba Empat: Jakarta.

Basu, Swastha. (2002). Marketing Management. Second Edition. Eighth Printing. Jakarta: Liberty Publishers

Basu Swastha and Irawan. (2013). Modern Marketing Management, Liberty, Yogyakarta. Law No. 20 of 2008 
Chenavaz, R. Y., Feichtinger, G., Hartl, R. F., \& Kort, P. M. (2020). Modeling the impact of product quality on dynamic pricing and advertising policies. European Journal of Operational Research, 284(3), 990-1001. https://doi.org/10.1016/ j.ejor.2020.01.035

Geovani, S.M, W., Ronald, S.T.,M.M, D., \& Amelia S.E., RFP-I., M.M., D. (2021). Analysis Of The Effect Of Product Quality, Product Style, Product Price, Brand Image, Service Quality And Store Environment Factors On Brand Loyalty On Uniqlo Customers In Surabaya. International Journal of Research Publications, 69(1). https://doi.org/10.47119/ijrp100691120211680

Iswayanti Ika Putri, (2010). Analysis of the Effect of Product Quality, Service Quality, Price and Place on Purchasing Decisions. Diponegoro University.

Kotler, P. (2007). Marketing Management Volume II (Indonesian edition). Jakarta: PT. Index.

Kotler, Philip, and Kevin Lane Keller. (2009). Marketing Management, 17e Global Edition, Pearson Education Limited, England.

Kotler, Philip. (2009). Marketing Management. Jakarta: Four Salemba

Kotler and Armstrong (2012) Gary Armstrong. Marketing Principles. Jakarta: Erlangga

Kotler, Philip, and Armstrong, Gary. (2008: 179). Marketing Principles. Jakarta: Erlangga,

Kotler, Philip and Keller, K. (2007). Marketing Management. Jakarta: PT. Index

Luthfia (2012) The Influence of Financial Performance, Company Size, Capital Structure, and Corporate Governance.

Nasution (2006). Approaches in Management Economics. Jakarta. Earth Literacy

Nursya'bani Purnama (2006: 9) Quality Management, Global Perspective, First Edition, Econisia Faculty of Economics.

Sangadji, Etta Mamang and Sopiah. (2013). Consumer behavior. Yogyakarta: Andi.

Tjiptono, Fandy. (2008). Marketing Management. Jakarta: Erlangga.

Tjiptono. (2008). Strategic Marketing, Issue 2. Yogyakarta: CV Andi. 